Smith, H. \& Lucas, I. A. M. (I957). F. agric. Sci. 49, 409.

Speer, V., Ashton, G., Diaz, F. \& Catron, D. (1953-4). Iowa Fm Sci. 8, no. Io, p. 3.

Teague, H. S. \& Carpenter, L. E. (195I). F. Nutr. 43, 389.

Terrill, S. W. (1957). Personal communication.

Venn, J. A. J., McCance, R. A. \& Widdowson, E. M. (1947). \%. comp. Path. 57, 314.

Walker, D. M. (1948). Studies in the nutrition of young dairy stock. Doctorate Thesis, University of Reading.

Warner, R. G., Flatt, W. P. \& Loosli, J. K. (1956). F. agric. Fd Chem. 4, 788.

Wise, M. B., Barrick, E. R., Wise, G. H. \& Osborne, J. C. (1954). F. Anim. Sci. 13, 365 .

Withers, F. W. (1952). Brit. vet. F. 108, 315.

Young, G. A. Jr. \& Underdahl, N. R. (1949). Cornell Vet. 39, 120.

Young, G. A. Jr. \& Underdahl, N. R. (1950). F. Immunol. 65, 369.

Young, G. A. \& Underdahl, N. R. (1953). Amer. F. vet. Res. 14, 57 I.

\title{
Idiopathic hypercalcaemia of infants
}

\author{
By R. G. Mitchell, Department of Child Health, University of St. Andrews
}

\section{Clinical features}

During the past 4 years, eighteen infants with the simple type of idiopathic hypercalcaemia have been treated in Dundee. The age of onset of symptoms ranged from the $3^{\mathrm{rd}}$ to the gth month, with the highest incidence in the 6 th and $7^{\text {th }}$ months. The clinical picture was remarkably consistent, the principal symptoms being anorexia, loss of weight, vomiting and constipation. About half of the infants showed fretfulness or apathy whereas the remainder were happy, contented infants despite their symptoms. In five of the eighteen cases there was a history of apparent difficulty in swallowing, an observation of some interest since Albright \& Reifenstein (1948) record this as a symptom of hypercalcaemia in adults.

Most of the infants were poorly nourished although this was not an invariable finding. Clinical dehydration was present in six of the eighteen on admission, but faecal masses were palpable in the abdomen of only two. The infants showed no consistent colour change, two having excessively red cheeks and two being unusually pale. A cardiac murmur was heard in three of the infants: in ten there were pus cells in the urine.

Hypercalcaemia was not diagnosed unless plasma-calcium determinations on two separate occasions showed levels above $12 \mathrm{mg} / 100 \mathrm{ml}$. At some time in their illness, all eighteen infants had a level of plasma calcium of ${ }_{3} 3 \mathrm{mg} / \mathrm{r} 00 \mathrm{ml}$. or over, and in two the level rose above $18 \mathrm{mg} / 100 \mathrm{ml}$. The blood urea level was above $50 \mathrm{mg} / 100 \mathrm{ml}$. in eleven of the eighteen. Levels of plasma cholesterol and alkaline phosphatase were variable and showed no consistent abnormality.

\section{Role of vitamin $D$}

The clinical features and the fact that calcium-balance studies had shown a high rate of calcium absorption from the intestine, suggested the possibility of a vitamin 
D effect, and the daily intake of the vitamin by these infants at the onset of symptoms was accordingly investigated. Exact measurement was impossible, but a reasonable estimate was made in each case by obtaining details of the diet as accurately as possible, by calculating the maximum and minimum probable intakes of vitamin D on that diet, and by taking the mean of the two values obtained. The intake could not be estimated in two infants because the date of onset was indeterminate but all the other sixteen infants were taking more than rooo i.u. vitamin D daily at the onset of symptoms, and eleven of them were taking more than 2000 i.u. daily. These amounts are higher than those recorded in most of the previous reports on hypercalcaemia of infants, because it has only recently become known that ergocalciferol was being added to dried milk and cereal foods in amounts considerably in excess of the stated contents, in order to allow for possible deterioration. Daily intakes of the order of 2000 i.u. have been shown to interfere with growth in children (Jeans \& Stearns, I938) but nevertheless such quantities are far less than the intakes reported in vitamin D poisoning. It appears probable that in the latter condition the parathyroid-like action of vitamin $\mathrm{D}$ is preponderant, whereas the harmful effects at the lower dose ranges may be attributable to an excessive physiological effect of vitamin $D$ in increasing absorption from the intestine. These two effects of vitamin $\mathrm{D}$ are in some respects antagonistic, and this fact may go far to explain the clinical differences between infants with idiopathic hypercalcaemia and those with vitamin $\mathrm{D}$ poisoning. It may also explain why in some instances the administration of large doses of ergocalciferol to infants with hypercalcaemia has not caused clinical deterioration, since such large doses may alter the balance between the two actions of the vitamin.

Individuals vary in their requirements for vitamin $\mathrm{D}$, and the infants who develop hypercalcaemia may represent those at one end of the range, whose requirements are very low. Nevertheless so many thousands of infants in Britain must have been receiving amounts of vitamin $\mathrm{D}$ of the same order, that it is tempting to postulate the existence of other factors which enhance the effect of the vitamin, so that infants who develop the syndrome are those unfortunate few in whom several such factors coincide.

In searching for such factors, consideration has been given to the effect of sunshine, the intake of calcium, the vehicle of administration of ergocalciferol, the principal source of nourishment, possible toxic constituents of cod-liver oil, the intake of alkali, and the incidence of infection. Cases of idiopathic hypercalcaemia occurred throughout the year, with no peak of incidence at any season, so that it is unlikely that sunshine played a significant part. Seventeen of the eighteen infants were fed on dried cow's milk fortified with ergocalciferol; thus their intake of calcium would be high, and the major part of their daily intake of ergocalciferol would be given in milk, which has been shown to enhance the activity of the vitamin (Lewis, 1935). It has been suggested (Sinclair, 1956) that idiopathic hypercalcaemia is the result of deficiency of essential fatty acids, owing to the low essential fatty-acid content of dried milk. The theory is an attractive one, although points against it are the absence 
of other signs of essential fatty-acid deficiency such as eczema, and the preponderance of females (twelve females to six males in this series, a $2:$ I ratio also being found in the series reported by Creery \& Neill (I954)), since in essential fatty-acid deficiency in animals, males have been affected five times more frequently than females. Moreover, it is by no means proven that vitamin $\mathrm{D}$ is esterified, although faulty esterification is the basis of Sinclair's argument.

At least four of the eighteen infants never had cod-liver oil, and only four had more than one teaspoonful daily, so that it is unlikely that any abnormal constituent of the oil played a part. Twelve of the infants had milk of magnesia administered regularly, so that alkali intake may have had an effect, on analogy with the milk and alkali syndrome of adults, as suggested by Creery (1953). Four infants, however, had no alkali medicine at any time.

Numerous cases of hypercalcaemia in infants have been reported from Finland (Hallman, 1955) in association with pneumonia, so that infection may play a part, although nearly all the Finnish infants were given large doses of ergocalciferol parenterally during convalescence. Investigation of the incidence of infection indicated that eight of the present eighteen cases had no history of infection at any time. Five of these eight did have pyuria, but in four the urine was sterile, and the presence of leucocytes in the urine does not necessarily indicate infection, since it may be the result of renal damage. In three of the eighteen cases, however, there was a clear history of infection just before the onset of symptoms, and in a further three cases infection after the onset seemed to result in an increase in severity of the symptoms. In about one-third of the cases, therefore, infection may have been a factor of importance.

\section{Treatment and prognosis}

Most infants with idiopathic hypercalcaemia recover spontaneously if they are given a diet low in calcium without added vitamin D. Various methods have, however, been tried in attempts to correct the metabolic disturbance more quickly. Sodium ethylenediaminetetraacetic acid has been tried but, although it is successful in lowering the plasma calcium, its use has been abandoned since it is too toxic (Morgan, Mitchell, Stowers \& Thomson, 1956). Sodium phytate has been given orally in order to reduce the absorption of calcium, but doses of $\mathrm{I} g$ daily did not alter the rate of absorption, and larger doses caused diarrhoea. Cortisone is effective in restoring the plasma calcium level to normal, and has been used in severe cases where urgent treatment was imperative. Cortisone increases the faecal excretion of calcium, but the effect on the plasma calcium cannot be entirely due to this action, since the plasma calcium falls within $8 \mathrm{~h}$ of giving a dose of cortisone, an effect too rapid to be due to the intestinal action. Since there is no outpouring of calcium in the urine immediately after administration of cortisone, the rapid fall in the plasma level must be produced by deposition of calcium in bone or soft tissues under the influence of cortisone.

Three of the eighteen infants died during the course of the illness and autopsy showed that they had extensive nephrocalcinosis (Rhaney \& Mitchell, r956). One 
further infant died later from pneumonia; there was no autopsy. Of the fourteen surviving children, twelve have been followed up for periods of $\mathrm{I}-4$ years. All twelve are free from symptoms and have apparently recovered completely. Two are still below the third percentile of weight for their age, three are in the roth percentile, three in the $25^{\text {th }}$, and four in the 5 oth. Only one is below the third percentile in height, three are in the third percentile, two in the Ioth, four in the 25 th, one in the

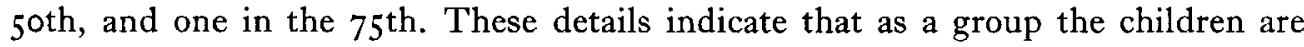
still below average height and weight, although they are not seriously retarded and it may be expected that they will achieve their expected growth levels in due course.

\title{
REFERENCES
}

Albright, F. \& Reifenstein, E. C. (1948). The Parathyroid Glands and Metabolic Bone Disease, p. 301. London: Baillière, Tindall and Cox.

Creery, R. D. G. (1953). Lancet, 265, i 7.

Creery, R. D. G. \& Neill, D. W. (1954). Lancet, 267, 1 10.

Hallman, N. (1955). Helv. paediat, acta, ro, I 19.

Jeans, P. C. \& Stearns, G. (1938). F. Pediat. 13, 730.

Lewis, J. M. (1935). F. Pediat. 6, 362.

Morgan, H. G., Mitchell, R. G., Stowers, J. M. \& Thomson, J. (1956). Lancet, 270, 925.

Rhaney, K. \& Mitchell, R. G. (r956). Lancet, 270, 1028.

Sinclair, H. M. (1956). Lancet, 271, IоI.

\section{Hypercalcaemia in infants and young animals}

\author{
By A. M. MacDonald, Royal Hospital for Sick Children, Glasgow
}

\section{Introduction}

The purpose of this paper is to discuss certain aspects of renal pathology in infants and in some young animals which may have a common aetiology. The material was derived from human-infant autopsies and animal experiments carried out on mice, rats, guinea-pigs, rabbits and calves with the strictly limited intention of comparing histological features in the kidneys in the different animal species under the conditions of the experiment with those found in the human infant.

Over the years there have been collected from routine autopsies in infants a series of observations on kidney lesions which in my experience are unlike any other lesion seen in the human infant.

The severe form has been adequately described and illustrated by Lowe, Henderson, Park \& McGreal (1954) and by Rhaney \& Mitchell (1956). Such a lesion invariably shows stainable calcium deposits, but with it a destructive granulomatous type of lesion is found often lacking in stainable calcium but nevertheless part of the disease process. Here one or more tubules are surrounded by granular debris in which round cells and few polymorph leucocytes and an occasional giant cell constitute the elements of the lesion. The surrounded tubule can be in any state of disintegration and sometimes is totally destroyed. Detailed examination of such 